UDK 792.01

821.163.42-93-31BRL:792.25

\title{
Željka Flegar
}

University of Osijek, Faculty of Teacher Education

zflegar@ufos.hr

\section{The Great Literary Improvisers}

Izvorni znanstveni članak / original research paper

Primljeno / received 25. 4. 2013.

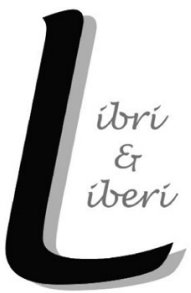

The paper discusses the principles and philosophy behind the art of improvising derived from the theory of improvisational theatre. The aim is to heuristically apply a typology of theatrical improvisation to the literary works of the Golden Age of Children's Literature in order to position the authors and the works of the Golden Age within the body, as well as to locate the Croatian 1913 classic Cudnovate zgode šegrta Hlapića [The Brave Adventures of a Shoemaker's Boy] by Ivana Brlić-Mažuranić within this defining era of children's literature. Due to the fact that improvisation is based on storytelling and that literature is reportedly conceived through images, this research aims to provide evidence that The Brave Adventures of a Shoemaker's Boy, much like the most prominent works of the Golden Age, is a superb example of the improvisatory process characterized by "bodily poeticizing" as defined by Lockford and Pelias (2004). The result of this creative process is the endurance, universality and adaptability of the works of the Golden Age, such as The Brave Adventures of a Shoemaker's Boy. Ključne riječi: archetype, bodily poeticizing, Golden Age of Children's Literature, improvisational theatre, literary pragmatics, realistic fiction, The Brave Adventures of a Shoemaker's Boy

\section{Improvisatory Images}

The nature of the origins of art, inspiration and imagination has been discussed for centuries. In her book The Art and Craft of Storytelling (2008), Nancy Lamb claims, "There is a mystery to writing. There is magic. Not in how we get our creativity, but how we use it. There is an element of surprise - of ideas appearing out of nowhere and connections leaping out of dreams - that cannot be accounted for in the daily living of our lives" (245). 
Similarly, the theory of theatrical improvisation, built on the foundation of commedia dell'arte, and further developed in the mid-twentieth century in the United States and Great Britain by Viola Spolin and Keith Johnstone, assumes that all inspiration and creation comes from initial spontaneous impulses and not deliberate reflection and contemplation: "[a]n artist who is inspired is being obvious. He is not making any decisions, he's not weighing one idea against the other. He's accepting his first thoughts" (Johnstone 1989: 88).

It is no surprise, then, that C.S. Lewis describes the origins of Narnia beginning with an image of "a Faun carrying an umbrella and parcels in a snowy wood" (Sammons 2004: 23), that J.R.R. Tolkien's work began on an empty page while Tolkien was grading his students' papers and spontaneously wrote the first sentence of The Hobbit (Carpenter 1977), that Baum got the idea for The Wonderful Wizard of $\mathrm{Oz}$ "right out of the blue" (McMaster 1992: 103) or that J.K. Rowling was sitting on a delayed train ride to London when "the idea of Harry Potter simply fell into my head“ (Rowling 2012).

In much the same way, Ivana Brlić-Mažuranić, one of the greatest Croatian children's authors, was inspired by the juxtaposition of a cheerful apprentice and his grumpy master that she encountered at a fair in Slavonski Brod, which resulted in Čudnovate zgode šegrta Hlapića, published in 1913 [The Brave Adventures of a Shoemaker's Boy] ${ }^{1}$ (Mihanović-Salopek 2001: 121). This Croatian classic about an orphan apprentice who sets off on a journey to break in the little boots that he had made too tight and do good deeds has been a source of wonder and inspiration for an entire century, resulting in numerous translations and adaptations on page, stage, radio and screen. ${ }^{2}$ The novel, much like its contemporaries of the Golden Age of Children's Literature, was conceived in the body and exhibits the obvious elements of improvisational behaviour, communication and perception.

Accordingly, "bodily poeticizing" as a typology (Lockford and Pelias 2004) will be used as a heuristic device to illustrate the shift towards the body which occurred during the Golden Age of Children's Literature, as well as to position The Brave Adventures firmly within this context as one of the classics of the Golden Age.

1 This paper uses the English translation by Theresa Mravintz and Branko Brusar, published in 1971. The name of the protagonist, Hlapić, is given as "Lapitch" in this edition. Other Croatian translations of the title include The Strange Adventures of Hlapich the Apprentice and The Brave Adventures of Lapitch, the latter being the title of the American edition which appeared in 1972.

2 Brlić-Mažuranić adapted the novel into a play (Lovrenčić 2006: 152, 259-94). Contemporary stage productions include those by Croatian children's and puppet theatres (Kazalište Trešnja and Gradsko kazalište Žar ptica in Zagreb, Dječje kazalište Branka Mihaljevića in Osijek, Kazalište lutaka Zadar). In 1967 and then in 2006 different radio plays based on The Brave Adventures were premiered on HR (Croatian Radio), in 1997 Croatia Film produced the animated film Lapitch the Little Shoemaker, and the latest live action feature titled Šegrt Hlapić directed by Silvije Petranović was released in 2013. 
The proposed typology which "relies upon the affective, physical, and vocal capacities of the performer" (Lockford and Pelias 2004: 432), signifies "thinking, intuiting, and feeling... with the body" (Roloff, qtd. in ibid.), and specifies "the performer's body as a site of knowing", while emphasizing the "act of doing as a way of coming to understand" (Lockford and Pelias 2004: 432), implies that the author, the literary product and the reader are inseparable entities, under the assumption that the sentiment and the personality of the author are largely reflected in the work of fiction and reconstructed during the process of reading.

The proposed methodology derived from improvisational theatre "privileges the sensuous, the experiential, the participatory" (ibid.). These also describe the features of children's literature that became apparent for the first time during the Golden Age, which distanced itself from didacticism and discipline prevalent in earlier works written for children. The Golden Age, because of the shift towards the body and its surroundings, became the point of origin for the terms 'childhood' and 'children's culture' as they are understood today. This analysis will, therefore, focus on the improvisatory "epistemic stances" of communication with which the author endows his or her characters and addresses the reader, on the playfulness and sedimentation characterizing the protagonist, the author and the reader who do not settle for literary lessons, but actively participate in the literary experience (albeit in an 'improper' fashion), as well as on the sensuality and vulnerability in the bodily perception of the internal processes, the environment and the regional subject matter. The listed categories will be presented by means of examples from The Brave Adventures of a Shoemaker's Boy by Ivana Brlić-Mažuranić in the context of the most prominent international works of the Golden Age of Children's Literature. As such, bodily poeticizing becomes a way of illustrating the childlike in the literary process of creation and reception which emerged during the Golden Age, as well as positioning one of the greatest Croatian children's classics within this context. By means of the proposed improvisational theories, the journey of the heroes of the Golden Age will be displayed as an improvisatory bodily process which changed the nature of writing for children. Finally, it is because of the shift in literature towards the body that the works of the Golden Age persevere, remain present as both regional and universal masterpieces, and are continually resurrected in the media.

\section{The Golden Age}

Although the nineteenth century was marked by poverty, unsanitary conditions, social neglect and mistreatment of children, it also marked a radical change in 
how children were perceived. Due to the Factory Acts, which limited child labour, the Education Acts, which raised the school leaving age, and medical discoveries which reduced infant mortality, the momentum leading to what is now known as a Golden Age of Childhood was developed (Messenger Davies 2011: 27). As a result, children were recognised as human beings extending beyond the image of small adults (Rogers 2008: 41), in other words, a group of individuals and consumers with a specific artistic taste and preferences. Accordingly, the Golden Age of Children's Literature began approximately in the mid-nineteenth century and continued up to the First World War (Hunt 2012; Messenger Davies 2011: 134).

This period constituted a true blossoming of children's books which for once did not aim to educate or patronize, but to properly entertain (Hunt 2012). In other words, the beginnings of children's literature offered religious and didactic materials aimed at children, such as hornbooks and primers, and although fables, fairy tales or novels such as Defoe's Robinson Crusoe (1719) were available to children, such texts were either used to indoctrinate, or were not intended for, aimed at or considered desirable for children (Zipes 2005: 175; Kinnell 1995). Consequently, during the Golden Age a significant shift was made from literature which targeted the lesson and the intellect, ${ }^{3}$ towards a type of literature which was produced primarily for children's enjoyment and was located in the bodily experience. As Hunt claims, "[ $t$ ]he most common view of the history of children's literature is that the books have progressed steadily from didacticism to freedom, or from strictness to corruption" (1995: xii).

Thus, the Golden Age put "some of the most influential, honest, and lasting children's stories into print" (Tunnel and Jacobs 2008: 45) such as Lewis Carroll's Alice's Adventures in Wonderland (1865), Hans Christian Andersen's Fairy Tales Told for Children (1835), Carlo Collodi's The Adventures of Pinocchio (1881), Mark Twain's 'bad boy' novels The Adventures of Tom Sawyer (1876) and The Adventures of Huckleberry Finn (1884), ${ }^{4}$ J.M. Barrie's Peter Pan (1904) and Frank L. Baum's The Wonderful Wizard of $\mathrm{Oz}$ (1900). The Golden Age thus implies international children's literature and works published in the Western World in the period between the mid-nineteenth century and the First World War, showing many

E.g., "When the Sun doth arise, you must get up each Day, / And fall on your Knees, and to God humbly pray; / Then kneel to your Parents, their Blessing implore; / And when you have Money, give some to the Poor. / Your Hands and your Face, in the next Place, wash fair; / And wish a good Morning to all in your View, / And bow to your Parents and bid them adieu" (Nurse Truelove's Christmas Box, c. 1750, qtd. in Avery 1995: 6).

${ }^{4}$ Children's literature scholars, including Hunt in Children's Literature - An Illustrated History (1995), place The Adventures of Huckleberry Finn within the children's literary canon. The characterization and the indigenous character of the novel make this work particularly suitable for comparison with Ivana Brlić-Mažuranić's book. 
similar features and trends characteristic of the period. Scholars claim that the Golden Age was an era of transition and change of which people were consciously aware and to which children's books wholeheartedly responded (Hunt 2012; Helson 1974: 68). Likewise, this period produced one of the most significant works in Croatian children's literature, namely The Brave Adventures of a Shoemaker's Boy by Ivana Brlić-Mažuranić.

\section{The Journey, Improvised}

Hlapic, ${ }^{5}$ the main protagonist of the novel, is a shoemaker's apprentice who, after having been mistreated by Master Scowler on account of boots which were made too small, runs away into "the wide world" (BASB": 14). Similarly, the Golden Age of Children's Literature features numerous journeys or quests, the structure of which ranges from conventional to nonsensical, often characterized by the act of running away, rebellion or displacement under circumstances beyond one's control. Dorothy, the Scarecrow, Tin Woodman and Lion are on their quests for home, brain, heart and courage, respectively; Huck travels "on the river and away from the corrupt society" (Goldman 2010: 4); Andersen's Gerda crosses the country in pursuit of her beloved Kai; and Alice's journey underground touches the part of ourselves that "has been beneath sight" (Stowell 1983: 8). Hlapić's encounters the man in black - his antagonist - and his homelessness and the constant change of place and environment are not unlike Alice's changes in size, reversals in logic or obliteration of time (Suchan 1978: 88). While on their quest for identity, conceivable adulthood and home, the heroes of the Golden Age, whether on their way to reach a mysterious garden or "lighting out for the territories" (McGillis 1983: 19), "must deal with events as they occur" (Moynihan 1973: 166-167) in an improvisatory process of "making stuff up as you go along" (Napier, qtd. in Zaunbrecher 2011: 49). In order to more closely define this type of journey as an improvisatory and bodily process, it will be observed in the light of the above-mentioned improvisational theories derived from the art of theatrical improvisation.

The journey of the little apprentice, much like that of his contemporaries, is distinctly archetypal. Though The Brave Adventures belong to the genre of realistic fiction, they equally contain layers of the universal. Jung defined archetypes as "primordial images" (2010: 12) which are inherent to the human psyche and common to all human experience, and whose most important application is in creative fantasy in which they are made visible (12-13). The main protagonist,

\footnotetext{
5 The main protagonist of the novel is referred to as Hlapic (original), Hlapich or Lapitch, depending on the translation. The author of this paper opted for the original version. See footnote 1, too.

${ }^{6}$ BASB refers to the 1971 English edition of The Brave Adventures of a Shoemaker's Boy.
} 
Hlapić the Apprentice, is a child archetype "who had neither father nor mother" (10), and who, much like Huck Finn, is on the threshold of adulthood in pre-war times (cf. Prusak 2011: 5). According to Berislav Majhut, an orphan as the protagonist of a children's novel adopts a position which is lower and less powerful than that of the intended reader; such a character is excluded from society, and passively suffers the blows inflicted by fate, until someone comes to the rescue (2005: 119-122). However, according to Martin, the lack of parental supervision makes characters open to journeys or quests in order for the protagonists to find their place within their community (2002: 16). This search for identity and restoration of the natural order includes many obstacles and perils which make it easier for an orphan to adopt the role of hero and undertake the quest and with which the reader can gladly identify.

Beckwith, for example, claims that "in no other American children's books do there seem to be so many orphans" (1976: 84-85) as in the Land of Oz series, and Alice and Peter Pan are dreamchildren whose stories fit within "a realm of literature which stares unblinkingly at the truth, which strides over flaws and inconsistencies, over the intellectual and social forces of our time, straight into the collective mind of its audience" (Rose, qtd. in Billone 2004: 181) and Pinocchio partakes in the "more inclusive process of becoming human" (Bettella 2004: 5). It is the confusion pertaining to the origins and search for clarity and order that propels the orphan on his or her quest.

Improvisational theatre, likewise, relies on the archetypal, having first appeared within the oral tradition of storytelling. Therefore, the primary goal of ancient improvisation, commedia dell'arte or the contemporary art of improvisation has been and is to tell stories. While establishing the theory of bodily poeticizing, Lockford and Pelias draw parallels between the act of improvisational performance and the process of creating a literary text, thus (Lee, qtd. in Lockford and Pelias 2004: 432):

The call to write is a call that is received in the body first. For hundreds of years poets and writers have described the creative process as a physical urgency, a sense that things will fly apart if they don't get the pencil to the page in time. Creativity is not tidy or polite - it's insistent. It calls us to feel, not dimly, not safely but wildly, passionately, in every cell and fiber.

Bodily poeticizing, in other words, is "a process of aesthetic engagement and judgement located in a corporeal presence" (Lockford and Pelias 2004: 432) and within this analysis it implies the authors, their fictitious products, and the participation of the reader. Although this typology is normally applied to actors who spontaneously create stories on stage, in this instance it is a lens through which one might observe the literary process of inspiration, creation and reception. In Literary Pragmatics, Mey discusses the relationships within literary discourse, thus (2003: 794): 
In the traditional view, authors create a text by inventing some characters, who then proceed to act out some series of events, called 'stories.' The characters are the author's 'creatures': we attribute the creational origin of a particular character (e.g. Huckleberry Finn) to its creator, a particular author (here Samuel Clemens, a.k.a. Mark Twain).

Accordingly, bodily poeticizing displays author-character-reader relationships through images which the author uses to build characters and which are then through images vicariously enacted and interpreted by the reader, accounting for numerous adaptations of the novels of the Golden Age for stage, radio, film or digital media. As Mey further notes (788):

The reader, as an active collaborator, is a major player in the literary game. His or her contribution consists in entering the universe that the author has created, and by doing so, becoming an actor, rather than a mere spectator. As a result, we do not only have cooperation, but also innovation. By acting the reader changes the play: what the reader reads is, in the final analysis, his or her own coproduction along with the author. I call this interaction a dialectic process..., inasmuch as the author depends on the reader as a presupposition for his or her activity, and the reader is dependent on the author for guidance in the world of fiction, for the 'script' that he or she has to internalize in order to successfully take part in the play...

Therefore, literature as an embodied experience at the levels of production and reception responds to the typology of bodily poeticizing comprised of the key epistemic stances of communication, playfulness, sedimentation, sensuality and vulnerability. Furthermore, the theory of theatrical improvisation deals with the spontaneous aspect of the performance, which at the same time must adhere to the structural determinants. All good improvisers are first of all noted craftspeople and professionals, and bodily poeticizing, therefore, encompasses the "embodied, cognitive, affective, and intuitive locations of [performance-derived] knowledges" (Lockford and Pelias 2004: 432) which constitute the creative pull similar to that of a writer (Lee, qtd. in Lockford and Pelias ibid.). According to Jackson, the defining characteristic of the character of Huckleberry Finn, who was created "in idle amusement in the summer of 1876", as "the freewheeling mixture of burlesque, satire, tall tale, and many other improvisations of technique and purpose" (Quirk 2012: 39), is "his industrious improvisation in any situation before him" (Jackson 2002: 60). Similarly, Alice spontaneously eats and drinks strange food and beverages, changes size, and repeatedly enters unknown spaces while attempting to communicate with the strangest folk she had ever encountered. As Carroll himself noted (qtd. in Helson 1974: 72-73):

I distinctly remember, how, in a desperate attempt to strike out some new line in fairylore, I had sent my heroine straight down a rabbit-hole, to begin with, without the least idea what was to happen afterwards. 
Examples of the improvisatory process are numerous in the emerging literature for children, and one of the most exquisite is The Brave Adventures of a Shoemaker's Boy. The following analysis demonstrates Hlapić's "epistemic stances" (Lockford and Pelias 2004: 432) of improvisatory communication, behaviour (playfulness and sedimentation), and perception (sensuality and vulnerability) in relation to his surroundings and those of his contemporaries, as features which became apparent for the first time during the Golden Age of Children's Literature.

\section{Improvisatory Behaviour or Worlds of Play}

Produced in 1904, the play Peter Pan, or the Boy Who Wouldn't Grow Up was a model of nineteenth century English pantomimes which was composed of fantastic effects, magic, flying, humour, harlequin clowns (Billone 2004: 187-188). According to Billone, in Barrie's world children are endowed with three skills which adults do not possess (191):

1) they can enter their own dreams and make these dreams come true, 2) they can play fantasy games in which the imaginary world takes the place of concrete reality; 3 ) they can fly (with the help of Pixie Dust and happy thoughts).

In accord with Twain's definition that "work consists of whatever a body is obliged to do, and that play consists of whatever a body is not obliged to do" (2005: 17), playfulness became the feature found in the most prominent works of the Golden Age for the first time ever, bringing "the pursuit of pleasure for its own sake into children's books" (Helson 1974: 72). Therefore, Alice's Adventures in Wonderland and its sequel Through the Looking-Glass, and What Alice Found There (1871) feature a series of games in which the rules of adult society, such as etiquette, education, edicts of law, rules of language and literary convention, are broken (Scott 1990: 21), but which have their own rules to follow, as is evident from the unusual treatment of croquet, chess, and card games.

Playfulness as a part of bodily poeticizing signifies opening oneself up to one's body's “expressive potential", being spontaneous, imaginative and ready to explore (Lockford and Pelias 2004: 434-5). Opulent with surprises in the choices that performers make, it is the "playfulness, the energizing and enabling fear, the search for consistency and the desire to respect co-actors" (436) that guide the performer or, in a novel, the character towards the completion of their task, which is indeed present in Brlić-Mažuranić's treatment of characters in The Brave Adventures of a Shoemaker's Boy. Not surprisingly, Ivana Brlić-Mažuranić reported that "when my small band of children began to grow and when they began to want to read, I felt at once that here was where inclination and duty became one, for I longed to be a writer“ (BASB: 7). 
Hlapić displays playfulness in his attitude and appearance as he prepares for the journey by putting on a pair of beautiful little boots, his green trousers, red shirt and shiny cap (BASB: 14), causing reactions such as, "My, what a sight you are! Are you a parrot or a woodpecker?" (19-20). Later on, the appearance of this little band of an unusually clad boy, his dog Bundash, Gita the circus girl that they encounter on the road and her parrot "makes an impression" (69) everywhere they go. This companionship proves to be on some occasions quite useful, as in the case of the merry-go-round owner who "thought they looked exactly right for the work and immediately took them on" (82). The companionship of child assistants or the pairing of protagonists is very common in novels of the Golden Age and constitutes the mythological dimensions of a narrative, such as the company consisting of the archetypal relation between Power, Knowledge and Love in The Wonderful Wizard of $\mathrm{Oz}$ (McMaster 1992: 106). As the child archetype often displays an androgynous character which symbolizes the potential merging of the opposites (Helson 1974: 72), the pairing of Hlapić and Gita is a common literary combination.

Gita, who is also an orphan, represents the Trickster, or the angelic, mischievous and idle counterpart to the industrious and sacrificing Hlapić, and encompasses mercurial trickster motifs such as a "fondness for sly jokes and malicious pranks, his powers as a shape-shifter, his dual nature, half animal, half divine, his exposure to all kinds of tortures, and - last but not least - his approximation to the figure of a saviour" (Jung 2010: 135). Up until the Golden Age when characters such as Tom Sawyer or Peter Pan were unleashed, mischief was not an integral part of children's texts. The stubbornness and aggression typical of children's behaviour appeared in English literature only at the end of 18th century in, for example, Mary Ann Kilner's Memoirs of a Peg-Top (c. 1781) and The Adventures of a Pincushion (c. 1780) ( $c f$. Avery and Kinnell 1995: 54). As a circus performer, Gita embodies the trickster tradition of Fools Holiday festivals celebrated in Middle Ages which were historically replaced by commedia dell'arte (138-140). Therefore, while listing her professional credentials, Gita prides herself on being able to "stand up on a horse and make it jump through a hoop", "juggle with twelve apples at a time", and "bite through a thick glass tumbler and swallow the pieces" (BASB: 38). She is lazy, easily bored (40), "trained for hoops and tightropes just for the sake of hoops and tightropes" (44). Yet, she manages to plot a scheme to punish the rich and boastful basket-maker at the fair and earn extra money for the poor one who had many children to feed, and though Hlapić "would never have played a trick like that himself [...] he laughed so much that his bag shook on his back" (79), whereas the poor basket-maker "thought she must be an angel sent from heaven to help him" (80). Much like the ambiguous Wonderland trickster the Cheshire Cat who is "good 
natured" but "has very long claws and very many teeth" (Stowell 1983: 7), which renders this character kind and dangerous at the same time, Gita has two sides. She is on the one hand nice, sensitive and compassionate, and on the other hand spoilt, at times selfish, and complicated. She slows Hlapić down and resists hard work, yet she is also sharp-witted and the source of ingenious ideas regarding survival, such as suggesting that Hlapić mend the herders' sandals so that they might spend the night in their house (BASB: 69), or entertaining the labourers during haymaking (42-44).

Though he might proceed on his journey faster without her, Hlapić does not abandon Gita because the Trickster represents growth, "is always present in the transformative journey, and his ultimate effect is positive; in fact, the presence of this ambivalent energy is crucial for change" (Stowell 1983: 5). It is noteworthy that Ivana Brlić-Mažuranić created the idle circus girl with particular tenderness and care, as if she were the love child of her most intimate thoughts. Brlić-Mažuranić's "lively and playful disposition" and her affinity for theatre are mentioned both in her autobiography, and by her biographers (Lovrenčić 2006: 152, 259-294). Therefore, Gita's previously unrehearsed performance for the labourers during haymaking is the most prominent example of playfulness and performing arts in the style of street theatre, circus and the tradition of commedia dell'arte. Gita appears as "the most dazzling sight", "like a queen in her golden dress, her hair streaming over her shoulders" in a little cart "that had held the drinking-water", all decorated, with Hlapić's dog Bundash pulling it, adorned with "a wreath of flowers round his neck and red bows on his tail" and "a pole was tied to the front of the cart and from a ring attached to this swung the parrot" (BASB: 42). Gita "spun like a top and hopped like a bird and beat a little drum", jumped through hoops "as easily as a fairy" (4243), walked the rope, sang "a strange kind of song which only circus people and parrots understand" (44) and managed to prepare the animals for the performance. While the audience is so full of admiration that "they were forgetting to eat their beans and potatoes", Hlapić, the author and the rest of us realise that it was quite "wonderful for Lapitch to share his journey with a friend who was wise and good in joy and in need!" (42). This playfulness permeates all that happens in The Brave Adventures, it is the reflection of the author's nature and is the source of images that engage the reader and viewer even today.

Throughout the novel, characters likewise display the skill of sedimentation. An improviser would describe sedimentation as an inexplicable moment in which they made a choice that they themselves could not comprehend, in other words "it just felt right" (Lockford and Pelias 2004: 436). Zaunbrecher considers this spontaneity a "primary feature of any improvisational performance act" (2011: 50). Sedimentation, according to Lockford and Pelias, implies the process in which 
performers "seek somatic signs, follow hunches, and trust impulses" (2004: 437). Possibly it is for this reason that Alice dares to taste the strange and the unknown, Huck befriends Jim despite the norms and expectations of his community, and Gerda knows that Kai is not dead.

In The Brave Adventures, Hlapić as a character makes intuitive decisions that significantly affect the course of events. The most prominent example of sedimentation is Hlapić's act of climbing up on the roof of a village house to put out the fire on the "fourth day of the journey" (BASB: 47-57). The act constitutes a decision which "responds to [the] immediacy" of the situation (Spolin, qtd. in Lockford and Pelias 2004: 436). The situation is described in the novel like this (BASB: 49):

Everybody looked up and there sat a little figure, wearing green trousers, a red shirt and a coloured cap. Some of you would have thought it was a fireman. But of course it was Lapitch who had scrambled up there while the people were wasting time quarrelling.

What follows this act is Hlapic falling through the roof into the loft which "really was a miracle" (51), as he falls into a bin of flour and subsequently finds in the loft all the stolen items he had been searching for, including the beautiful little boots which the man in black took during the storm (51-52). Therefore, a potentially fatal event brings Hlapić closer to justice and the fulfilment of his own desires, evident in the scene in which "[t]hey picked up Lapitch out of the flour and carried him shoulder-high to the courtyard. Nursing his precious boots, he felt as happy as a king" (52). It is conceivable that Brlić-Mažuranić's practice of telling stories to her own offspring resulted in the creation of characters who spontaneously contribute to the circumstances arising. The resourcefulness of such characters became the staple of child characters as we know them today. While following them on their journey, a child reader not only learns, but also participates in a lifelike bodily adventure.

\section{Improvisatory Communication}

Lockford and Pelias deem communication fundamental to any performance (2004: 433). Due to the fact that they adopt Burleson's definition of communication as "a process of message production, message reception and interactional coordination" (Lockford and Pelias 2004: 433) in which performers are encouraged to "listen carefully to each other to be open to what is being said", in other words "accept offers" and avoid "blocking" (Johnstone 1989; Wirth, qtd. in Lockford and Pelias 2004: 433), improvisational communication implies coordination and negotiation, adapting to the circumstances arising and drawing on the performers' 
cognitive, affective and intuitive skills. Offers in improvisation are verbal, nonverbal, intentional or unintentional cues received from the environment to which the performer needs to respond with urgency in order to shape their own reality. In doing so, however, the performers must at all times follow linguistic rules and the conventions derived from the game structure. Such is the case, for example, in Alice's Adventures in Wonderland in which superficially all rules of logic are broken, yet Carroll as a scholar is able to create wordplay and nonsense precisely because he is exactly aware of the rules of the game.

Likewise, playful exchanges as a reflection of the author's nature ${ }^{7}$ are present in The Brave Adventures of a Shoemaker's Boy, though not in the least in an anarchic manner. They retain the essential benevolence, clarity and simplicity which permeate the entire novel, as, for example, when Hlapić asks the milkman "why such a clever animal should be called a donkey or an ass" (BASB: 21) or when he tells Yana the beggar that "the emperor has sent me on a journey through this country to give help where help is needed" (72-73) which was "nonsense of course but it made old Yana laugh and Lapitch started on her sandals right away" (73). Furthermore, Gita's trickster nature shines out when to Hlapić's "Here's the donkey!" she retorts "Did you mean yourself?" (118).

Most importantly, communication as a vehicle of trust, support, cooperation (Izzo, qtd. in Lockford and Pelias 2004: 434) and respect is the chief marking of The Brave Adventures. Brlić-Mažuranić's omniscient narrative voice speaks directly to the reader in a manner of the oral tradition of storytelling and most likely as a result of her rapport with her own children. She does indeed tell of the olden days, when "people used to tell stories about elves and witches and vampires meeting at crossroads" (BASB: 58) and even lets Hlapić retell the tale of "The Princess and the Pea" (84-85). Further examples of her storytelling discourse include "This was the first day of Lapitch's travels, and it had a happy ending. What would the next day bring?" (28), "It was a happy evening so it is worth telling it in full, although it is not otherwise important. For most people the cheerful things are the most important, anyway" (41) or "Well, if you've read this book so far and if you're fond of Lapitch perhaps you'd better close this book now and wait until tomorrow!" (102). Brlić-Mažuranić also displays much tenderness and respect for her main protagonist, as is obvious from her statements, "How kind and good Lapitch was and what a long way he had to tramp on his little feet!" (BASB: 94), "But Lapitch was a poor child and poor children get to know the whole world" (92).

In Searching for Ivana (2006) Lovrenčić describes Ivana Brlić-Mažuranić as an extremely sociable individual who enjoyed company and participation in various social events 
The authorial voice is reflected in the character because Hlapic employs most of the features of improvisatory communication. He treats the people that he encounters on the road, his companions, and even his enemies, with respect. Because he easily picks up cues from his environments, he offers help to the old milkman, helps Marko find his geese, communicates with the stone-breakers in such a manner that they conclude, "Your boots are good and you've just proved you have strong hands and a clever head" (BASB: 31-32). He also cooperates with his dog Bundash, which is why "For every piece he put in his own mouth he threw one to Bundash, who caught it in the air and swallowed it in one gulp" (2324). Consequently, Hlapić approaches people spontaneously, such as Gita, "I'm on a journey, too [...] So let's go together" (38) or a farmer, "Could you use good workers?" (39). By communicating freely with the people he encounters, Hlapić obtains valuable information needed to continue his journey. By showing respect and support for his fellow creatures, such as warning the man in black's accomplice Gregory on behalf of his mother (53), Hlapić affects a number of events which bring about a transformation of characters such as Gregory and Master Scowler, as well as the restoration of the natural order, family and identity, which supports the notion (Ornish, qtd. in Ryan Madson 2005: 123) that:

[...] we are creatures of community. Those individuals, societies and cultures who learned to take care of each other, to love each other, and to nurture relationships with each other during the past several hundred thousand years were more likely to survive than those who did not.

It is no surprise, then, that works of the Golden Age, such as The Brave Adventures of a Shoemaker's Boy, became the model and inexhaustible resource for children's literature as we know it today.

\section{Improvisatory Perception}

Ivana Brlić-Mažuranić was a keen observer of her surroundings ("Put, istina i život Ivane Brlić-Mažuranić”). Born in picturesque Ogulin, which nourished her imagination to such an extent that it made her contemplate "images and fantastic possibilities long into the night" (Brlić-Mažuranić 1916), and then moving to Karlovac, Zagreb, and eventually to Slavonski Brod, where she spent the remainder of her life, Ivana Brlić-Mažuranić experienced both the flair of the city and the sensory input of the country so evident in her work. While creating The Brave Adventures of a Shoemaker's Boy, Brlić-Mažuranić wanted to achieve "the simplicity and clarity of language", the result of which was a surprise: "the character of little Hlapić emerged from this book sweeter and clearer than he was in my thoughts" (Brlić-Mažuranić 1916). 
Accordingly, the improvisatory features of sensuality and vulnerability correspond to the author's sentiment and determine the mood of the novel. Augusto Boal encouraged actors to "feel what they touch, to listen to what they hear, and to see what they look at", which is why "this bodily sensitivity, this sensory alertness, this physical presentness is a source of knowledge that fuels the dynamic of an improvised moment" (Lockford and Pelias 2004: 437). The sensory and perceptual feature of children's literature was clouded in the period prior to the Golden Age by the need to teach and promote obedience. As opposed to that, the authors of the Golden Age freely made use of sensory images from their immediate surroundings, possibly under the influence of the Romantic movement. In Searching for Ivana, Sanja Lovrenčić relates Ivana Brlić-Mažuranić's first encounter with the magic of writing after she had been told by her teacher that "a sentence can contain the world" whereupon, in the quoted words of the novelist herself, "examples started flowing like a deluge from my new forge [...]. These pictures tossed into a sentence kept bouncing back off the paper like an imprint into my mind and - my first literary work was done!" (2006: 54). Brlić-Mažuranić's descriptions of the surroundings and natural phenomena are very simple, yet extremely sensory, such as "It was a hot, sultry day and a storm was brewing" (BASB: 32), or "Their road lay amongst vast meadows, like a long piece of straw laid across a green sea, and Lapitch and Gita walked along the road like two ants along the straw" (58). The countryside spaces come to life through the depictions of precious moments, such as (48):

Never in his life had Lapitch slept as well as he did that night. It is lovely to sleep on hay in the summer. The hay smells wonderful, everything is peaceful, nobody is awake. In the country all good people sleep at night. Only owls and bats are about and even they fly silently. They could not wake up Lapitch.

Finally, emotions spring forth in descriptions such as "The joy seemed to flood the room with golden light" (BASB: 113), which reflect both the author's style and output, as well as the condition of the protagonists.

Likewise, The Brave Adventures of a Shoemaker's Boy very successfully depicts the setting in which it was created, as the author captures the essence of her native and domicile regions. As a realistic novel, The Brave Adventures of a Shoemaker's Boy respects the laws of its universe, a characteristic of realistic fiction, and portrays the country landscape where "many carts and peasant folk passed by on the road. The carts creaked, the horses' hoofs clattered, the people shouted to one another and the geese that were being carried to market quacked and hissed" (BASB: 23). This is a place where "there was such a lot of noise that Lapitch woke up, and at first he thought he must be in a menagerie. In a village there is always this kind of noise in the morning, but he did not yet know that" (30), 
where "soon he could not see a single house anywhere - only vast fields, bushes, trees and the long road stretching out in front of him" (22). Brlić-Mažuranić very faithfully illustrates Hlapić's encounter with the stone-breakers (30), the labourers, villagers putting out a fire (48) and herders. In the course of the story, Hlapić and Gita also arrive in a large town (74):

It was so big that it had a church with two steeples and ten small ones with one steeple each. It had a hundred streets and people milling around them like ants.

The author shows the size of the town by means of the description of a large fair, at which (74):

there were two hundred stalls, large and small. You could buy red handkerchiefs, black coats, blue pottery and yellow melons. There was a great beating of drums and shrilling of whistles because many people were buying toys as well.

According to Beckwith, the "native" or "indigenous" subject matter (1976: 76) is the essential ingredient of the novel and the reason for its vitality, also present in other works of the Golden Age, such as the first American "fairy tale" The Wonderful Wizard of $\mathrm{Oz}$ and the "Great American novel" The Adventures of Huckleberry Twin, as well as in The Adventures of Pinocchio (1881), "one of the best novels in Italian Ottocento narrative" which "best expresses the Italian character" (Bettella 2004: 4). More than anything, it is the author's relationship to the region that is the constant source of wonder, amusement and "emotional reality" (Jackson 2002: 47).

Moynihan claims that stories told or written for children often represent the dominant values of a society (1973: 166), a feature which became very distinguishable during the Golden Age (Hunt 2012). Thus, Alice struggles with Victorian rules and Huck Finn contemplates the institution of slavery. In accord with that, Ivana Brlić-Mažuranić's novel neatly depicts pre-war Croatia on its way towards a transition between countries and identities, as she concludes in her "Autobiography" (1916):

Which of us knows his soul well enough to foretell how it will emerge from such trials, how it will be transformed, which sentiments will evade it, and which, thus far inconceivable revelations, will occur once we've suffered through this period.

We shall combine at this point the stance of sensuality and vulnerability for the purpose of describing the culmination and the final stage of the quest, namely the scene in the woods. Natural weakness and acceptance of failure appeared during the Golden Age as child protagonists began displaying natural child behaviour, in contrast to their predecessors who strived for perfection and heavenly reward. As Hlapić and Gita, towards the end of the novel, begin their journey at night in order to warn Marko and his mother in the house with the blue star painted on it that the 
man in black was coming to steal their cow, they encounter a setting of extreme vulnerability, described in the following way (BASB: 95):

Walking through meadows in the middle of the night is like walking in a dream. Big night-moths flew past their heads beating their wings like birds. Gita saw an old hedgehog trotting beside them on the grass, and now and again in the meadows they caught a glimpse of hares' ears sticking out of the grass. They heard birds rustling in the bushes.

Vulnerability in The Brave Adventures is manifested in homelessness and a lack of protection characteristic of an orphan. In improvisational theatre "when the actor experiences vulnerability, he may be gripped by a kind of imaginative stumping. The actor is thrown out of the scene and posed with the challenge to either break or remake the scene" (Lockford and Pelias 2004: 438). The stance of vulnerability does not necessarily need to lead to a breakdown, but may in fact be productive and cause the revitalising of one's own position, in other words, lead the performer in a new unanticipated direction. Most of the heroes experience a state of vulnerability, such as Dorothy and Alice in unknown lands of self-doubt (McMaster 1992: 104), Gerda who exposes herself to the forces of nature because of her "own failure to mourn" (Weitzman 2007: 1116), Huck whose arguments "fall on the wrong side" (Goldman 15-16) or Peter Pan who cannot bring himself to grow up. Likewise, all of them reinvent themselves from vulnerable circumstances, including Hlapić who tells Bundash, upon the stealing of his boots by the man in black (BASB: 36 ):

We'll look for him, Bundash, and we will find him if it takes us ten years! And we'll get the boots back, even if he hides them in the emperor's chimney!

The villain named "the man in black" is an archetypal figure which Clarissa Pinkola Estés, in her celebrated book Women Who Run With the Wolves, defines as "the natural predator of the psyche" who often appears as a "universal initiatory dream among women" (1995: 67). This character is the epitome of all evil in Hlapić's world, the original villain who "laughed as evilly as only bad men can laugh when they talk about their wicked deeds" (BASB: 92). Therefore, the conquering of the man in black signifies the restoration of the natural order, transformation and selfdiscovery. In this way, the images found on the pages of The Brave Adventures indicate a transformative journey. Though Hlapić indeed finds the boots, the man in black continues to commit evil deeds, one of which brings the children into the thicket at night. Interestingly enough, according to Jung, the woods are a mother symbol representative of the dual nature of the mother which includes magic authority, wisdom, spiritual exaltation, instinct, growth and fertility, magic transformation and rebirth, but also darkness, secret, and anything that is "terrifying 
and inescapable like faith" (2010: 139). Thus, in the woods, Hlapić and Gita find more than they had hoped for, for it was Master Scowler who was in fact robbed on his way to the fair (BASB: 104):

For two whole days Master Scowler remained tied to the tree, and as he was quite sure that there was no help for him, he commended his soul to God. He remembered everything he had done in his life, good and evil, and he also remembered Lapitch and longed to see him once more. When a man is tied to a tree for two days without food or drink, he has plenty of time to ponder, and the way he thinks about his apprentice then is quite different from when he is shouting at him in the workshop.

The reunion with Master Scowler who had seen the error of his ways because of his own state of vulnerability is in fact a reunion of a family separated long ago. Like Huck, Alice, Gerda, or Dorothy, Gita and Hlapić returned to society, were reintegrated into their family unit, ${ }^{8}$ and when they grew up (119):

They had four children and three apprentices. And sometimes, on Sunday afternoons, the children and the apprentices would gather round to listen to the story of Hlapić's wonderful adventures. His boots stood in a glass case, where everybody could see them.

Much like Alice's or Wendy's, Hlapić's journey turns him into a storyteller (McGillis 1983: 20; Suchan 1978: 91) who makes the eyes of children "bright and eager with many a strange tale, perhaps even with the dream of Wonderland of long ago" (Carroll 1981: 97). Having become storytellers and original improvisers, such characters do not recall the hardships of their journeys but rather moments of the playfulness and joy of childhood. As Lucy Maud Montgomery wrote, "Only a few, who remain children at heart, can ever find that fair, lost path again, and blessed are they above mortals [...]. The world calls them its singers and poets and artists and storytellers..." (McGillis 1983: 20). In the end, it is no wonder that Ivana BrlićMažuranić, Hlapić and Gita inspire us to vicariously enter and reinvent their story a hundred years later.

\section{Conclusion}

Viola Spolin, the "mother of improvisational theatre" claimed that "when response to experience takes place at this intuitive level, a person functions beyond a constricted intellectual plane, intelligence is freed" (1999: 3). Accordingly, the improvisers of the Golden Age display intelligence in handling themselves and their surroundings, which is located in the body. Hlapićs artistic and theatrical features might be the reason why the novel is gladly interpreted, performed and

${ }_{8}$ Gita is, in fact, Master and Mistress Scowler's long lost daughter. 
adapted. The great literary improvisers of the Golden Age such as Hlapić, Alice, Peter, Pinocchio, Gerda, Dorothy, Tom or Huck built a foundation on which all literature for children is based. They evoked enjoyment and entertainment which became the most important staple of modern childhood and its products. Their quest is grounded in cultural circumstances, as well as psychological truth. More than anything, however, it is grounded in images, those which Jung claimed to "rise to the surface in dreams and in the visions of artists to restore the psychic balance, whether of the individual or of the epoch" (Helson 1974: 74). Those are the images to which Ivana Brlić-Mažuranić aspired, whose solace she sought and which she so generously left behind. Thus, to Hlapić we owe the suspense and beauty of the Croatian children's novel, and to the works of the Golden Age we owe children's literature as we know it today. Much like Twain, Brlić-Mažuranić belongs with "the great restless creators who never strove for one kind of perfection because perhaps they had something better to do" (Wood Krutch, qtd. in Quirk 2012: 48). It is precisely because of the bodily images of playfulness, interaction, sedimentation, sensuality and vulnerability that the improvisers of the Golden Age keep returning to us, in thoughts, on page, stage and screen "as cheerful as a bird, as brave as a knight, as wise as a book and as good as the sun" (BASB: 119).

\section{References}

\section{Primary Sources}

Brlić-Mažuranić, Ivana. 1913. Čudnovate zgode šegrta Hlapića. Zagreb: Hrv. pedagoškoknjiževni zbor.

Brlić Mažuranić, Ivana. 1971. The Brave Adventures of a Shoemaker's Boy. Transl. by Theresa Mravintz and Branko Brusar. London: J M Dent \& Sons Limited.

Carroll, Lewis. 1981. Alice's Adventures in Wonderland and Through the Looking-Glass. New York: Bantam Books.

Twain, Mark. 2005. The Adventures of Tom Sawyer. London: Bounty Books.

\section{Secondary Sources}

Avery, Gillian. 1995. "The beginnings of children's reading to c. 1700." In Children's Literature - An Illustrated History, edited by Peter Hunt, 1-25. Oxford: Oxford University Press.

Avery, Gillian \& Margaret Kinnell. 1995. "Morality and Levity (1780-1820)." In Children's Literature - An Illustrated History, edited by Peter Hunt, 46-76. Oxford: Oxford University Press.

Beckwith, Osmond. 1976. "The Oddness of Oz." Children's Literature 5: 74-91.

Bettella, Patrizia. 2004. "Pinocchio and Children's Literature." Quaderni d'italianistica 25 (1): 3-8. <http://jps.library.utoronto.ca/index.php/qua/article/viewFile/9216/6179> (accessed April 15, 2013).

Billone, Amy Christine. 2004. "The Boy Who Lived: From Carroll's Alice and Barrie's Peter Pan to Rowling's Harry Potter." Children's Literature 32: 178-202. 
Brlić-Mažuranić, Ivana. 1916. “Autobiografija” [Autobiography]. U svijetu bajki Ivane Brlić-Mažuranić. <http://www.usvijetubajki.org/ivana_brlic-mazuranic/autobiografija/ default.aspx $>$ (accessed March 1, 2013).

Carpenter, Humphrey. 1977. Tolkien: A Biography. New York: Ballantine Books.

Goldman, Alan. 2010. "Huckleberry Finn and Moral Motivation." Philosophy and Literature 34 (1): 1-16.

Helson, Ravenna. 1974. "The Psychological Origins of Fantasy in Mid-Victorian England." Children's Literature 3: 66-76.

Hunt, Peter. 1995. "Editor's Preface." In Children's Literature - An Illustrated History, edited by Peter Hunt, ix-xiv. Oxford: Oxford University Press.

Hunt, Peter. 2012. "The Golden Age of Children's Literature." OUPAcademic. <http:// www.youtube.com/watch? $v=$ g-Hmfkve3pQ $>$ (accessed March 15, 2013).

Jackson, Robert. 2002. “The Emergence of Mark Twain's Missouri: Regional Theory and Adventures of Huckleberry Finn." The Southern Literary Journal 35 (1): 47-69.

Johnstone, Keith. 1989. Impro: Improvisation and the Theatre. London: Methuen Drama.

Jung, C.G. 2010. Four Archetypes. Princeton and Oxford: Princeton University Press.

Kinnell, Margaret. 1995. "Publishing for children (1700-80)." In Children's Literature - An Illustrated History, edited by Peter Hunt, 26-45. Oxford: Oxford University Press.

Lamb, Nancy. 2008. The Art and Craft of Storytelling: A Comprehensive Guide to Classic Writing Techniques. Cincinnati: Writer's Digest Books.

Lockford, Lesa \& Ronald J. Pelias. 2004. "Bodily Poeticizing in Theatrical Improvization: A Typology of Performative Knowledge." Theatre Topics 2: 431-443.

Lovrenčić, Sanja. 2006. U potrazi za Ivanom [Searching for Ivana]. Zagreb: Autorska kuća.

Lynch-Brown, Carol \& Carl M. Tomlinson. 2004. Essentials of Children's Literature. Allyn \& Bacon.

Majhut, Berislav. 2005. Pustolov, siroče i dječja družba [An Adventurer, an Orphan and the Children's Band]. Zagreb: FF press.

Martin, Philip. 2002. The Writer's Guide to Fantasy Literature: From Dragon's Lair to Hero's Quest. Kalmbach Publishing Co.

McGillis, Roderick. 1983. "Fantasy as Adventure: Nineteenth Century Children's Fiction." Children's Literature Association Quarterly 8 (3): 18-22.

McMaster, Juliet. 1992. "The Trinity Archetype in The Jungle Books and The Wizard of Oz." Children's Literature 20: 90-110.

Messenger Davies, Máire. 2011. Children, Media and Culture. McGraw Hill: Open University Press.

Mey, Jacob L. 2003. "Literary Pragmatics.” In The Handbook of Discourse Analysis, edited by Deborah Schiffrin, Deborah Tannen \& Heidi E. Hamilton, 787-816. Malden: Blackwell Publishing.

Mihanović-Salopek, Hrvojka. 2001. "Pogovor" [Afterword]. In Čudnovate zgode šegrta Hlapića by Ivana Brlić-Mažuranić, 121-123. Zagreb: Tiskara Znanje.

Moynihan, Ruth B. 1973. "Ideologies in Children's Literature: Some Preliminary Notes." Children's Literature 2: 166-172.

Official website of the City of Slavonski Brod. $<$ http://www.slavonski-brod.hr/en/> (accessed March 28, 2013).

Pinkola Estés, Clarissa. 1995. Women Who Run With the Wolves. New York: Ballantine Books.

Prusak, Bernard G. 2011. "When Words Fail Us: Reexamining the Conscience of Huckleberry Finn." The Journal of Aesthetic Education 45 (4): 1-22. 
"Put, istina i život Ivane Brlić-Mažuranić" [The Way, the Truth, and the Life of Ivana BrlićMažuranić]. U svijetu bajki Ivane Brlić-Mažuranić. <http://www.usvijetubajki.org/ ivana_brlic-mazuranic/autobiografija/default.aspx $>$ (accessed March 1, 2013).

Quirk, Tom. 2012. "The Flawed Greatness of Huckleberry Finn." American Literary Realism 45 (1): 38-48.

Rogers, Jacquelyn. 2008. "Picturing the Child in Nineteenth-Century Literature: The Artist, the Child and the Changing Society." Children and Libraries 3: 41-46.

Rowling, J. K. 2012. "It All Started on Platform 93/4." J.K. Rowling. <http://www.jkrowling. com> (accessed April 1, 2013).

Ryan Madson, Patricia. 2005. Improv Wisdom: Don't Prepare, Just Show Up. New York: Bell Tower.

Sammons, Martha C. 2004. A Guide Through Narnia. Regent College Publishing.

Scott, Carole. 1990. "Limits of Otherworlds: Rules of the Game in Alice's Adventures and the Jungle Books." (Proceedings). Children's Literature Association Quarterly 20-24.

Spolin, Viola. 1999. Improvisation for the Theater. Evanston: Northwestern University Press.

Suchan, James. 1978. “Alice’s Journey from Alien to Artist.” Children 's Literature 7: 78-92.

Stowell, Phyllis. 1983. "We're All Mad Here." Children's Literature Association Quarterly 8 (2): 5-8.

Tunnell, Michael O. \& James S. Jacobs. 2008. Children's Literature, Briefly. Upper Saddle River, NJ: Pearson.

Twain, Mark. 2005. The Adventures of Tom Sawyer. London: Bounty Books.

Weitzman, Erica. 2007. "The World in Pieces: Concepts of Anxiety in H.C. Andersen's 'The Snow Queen." MLN (Comparative Literature Issue) 122 (5): 1105-1123.

Zaunbrecher, Nicholas J. 2011. "The Elements of Improvisation: Structural Tools for Spontaneous Theatre." Theatre Topics 21 (1): 49-60.

\section{Željka Flegar}

Sveučilište u Osijeku, Učiteljski fakultet

Universität Osijek, Fakultät für Lehrerbildung

\section{Veliki književni improvizatori}

U radu se predstavljaju filozofija $i$ načela na kojima počiva umjetnost improvizacije, a koja potiču iz teorije improvizacijskoga kazališta. U istraživanju se heuristički primjenjuje tipologija kazališne improvizacije na književna djela Zlatnoga doba dječje književnosti kako bi se autore i djela Zlatnoga doba pozicioniralo unutar tjelesne i perceptivne poetike te utvrdilo pripadnost hrvatskoga klasika, realističnoga dječjega romana Čudnovate zgode šegrta Hlapića (1913) Ivane Brlić-Mažuranić tom odlučujućem razdoblju dječje književnosti. Zbog činjenice da se umjetnost improvizacije zasniva na pripovijedanju, a književnost, riječima slavnih književnika, stvara kroz slike, cilj je ove analize iznjedriti dokaze kako su Čudnovate zgode šegrta Hlapića, poput ostalih najvažnijih međunarodnih djela Zlatnoga doba, također vrhunski primjer improvizacijskoga procesa, koji se očituje kroz "poetiku tijela” kako ju definiraju Lockford i Pelias (2004). Rezultat ovoga kreativnoga procesa je 
istrajnost, univerzalnost i prilagodljivost književnih djela Zlatnoga doba, a među njima $i$ dječjega romana Čudnovate zgode šegrta Hlapića.

Ključne riječi: arhetip, poetika tijela, Zlatno doba dječje književnosti, kazalište improvizacije, književna pragmatika, realistični roman, Čudnovate zgode šegrta Hlapića

\section{Große literarische Improvisatoren}

Im Beitrag werden die aus der Theorie des Improvisationstheaters stammende Philosophie und die auf ihren Grundsätzen beruhende Improvisationskunst vorgestellt. In typologischer Anwendung der Theaterimprovisation auf literarische Werke aus der kinderliterarischen , Goldenen Zeit', werden die ihr zugerechneten Autoren und Werke innerhalb der leiblichen und perzeptiven Poetik verortet. Darüber hinaus wird die Zugehörigkeit des realistischen Kinderromans und kroatischen Klassikers Čudnovate zgode šegrta Hlapića [Wunderbare Reise des Schusterjungen Clapitsch] (1913) von Ivana Brlić-Mažuranić zu diesem signifikanten Zeitabschnitt in der Kinderliteratur aufgezeigt. Ausgehend von der Tatsache, dass die Improvisationskunst auf dem Erzählen beruht und die Literatur nach Meinung bekannter Schriftsteller durch Bilder geschaffen wird, wird im Beitrag dargelegt, dass der Roman Šegrt Hlapić analog zu den herausragenden internationalen Werken der, Goldenen Zeit' ein Musterbeispiel für Improvisationsprozesse darstellt, wie sie Lockfold und Pelias (2004) in der „Körperpoetik“ definieren. Das Ergebnis dieser kreativen Prozesse manifestiert sich in Fortbestehen, Universalität und Adaptionsmöglichkeiten literarischer Werke aus der , Goldenen Zeit', wie dem Kinderroman Šegrt Hlapić.

Schlüsselwörter: Archetyp, Körperpoetik, ,Goldene Zeit' der Kinderliteratur, Improvisationstheater, literarische Pragmatik, realistischer Roman, Čudnovate zgode šegrta Hlapića 


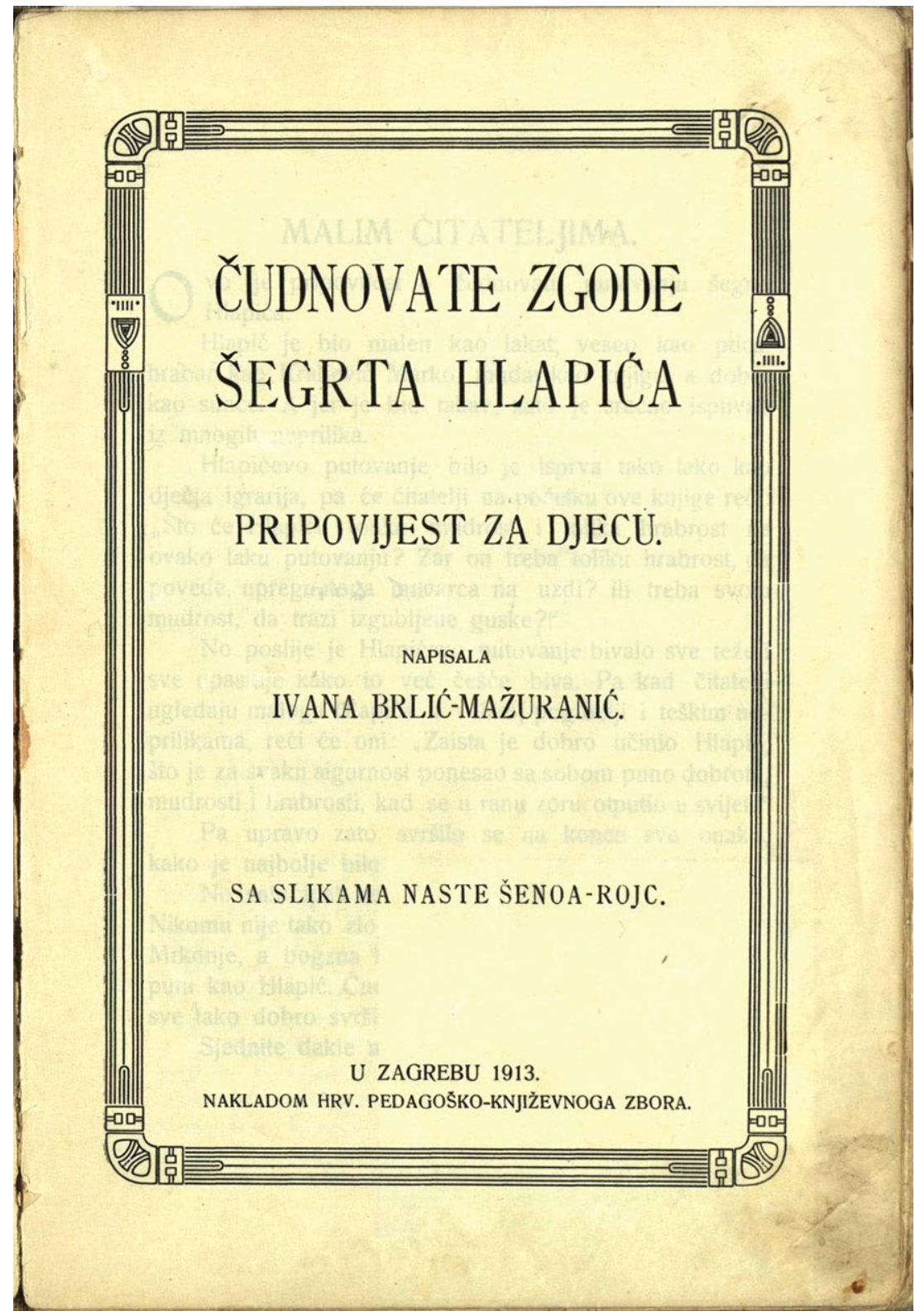

Naslovni list prvoga izdanja Čudnovatih zgoda šegrta Hlapića iz 1913. godine. Digitalno izdanje Knjižnica grada Zagreba u zbirci Digitalizirana zagrebačka baština, dostupno na <http://kgzdzb.arhivpro.hr/>.

Title page of the first edition of The Strange Adventures of Hlapich the Apprentice, 1913. Digital edition by Zagreb City Libraries in the collection

Digitized Zagreb Heritage available at <http://kgzdzb.arhivpro.hr/>. 